\title{
Correction to: Recurrent spontaneous abortion related to balanced translocation of chromosomes: two case reports
}

Xue Wan ${ }^{1,3+}$, Linyan Li ${ }^{1,2+}$, Zulin Liu', Zhenhai Fan ${ }^{1,2}$ and Limei Yu ${ }^{1,2^{*}}$

\section{Correction to: J Med Case Rep (2021) 15: 270} https://doi.org/10.1186/s13256-021-02848-9

Following publication of the original article [1], the authors identified an error in the affiliations 1-3.

Affiliation 1 and 3 should also include: Affiliated Hospital of Zunyi Medical University

Affiliation 2 indicated Zunyi Medical University Hospital while it should instead read: Affiliated Hospital of Zunyi Medical University

The affiliations have been updated in the correction article and the original article [1] has been corrected.

\section{Author details}

${ }^{1}$ Key Laboratory of Cell Engineering in Guizhou Province, Affiliated Hospital of Zunyi Medical University, Zunyi 563003, Guizhou, China. ${ }^{2}$ Guizhou Provincial Sub-center for Prenatal Diagnosis, Affiliated Hospital of Zunyi Medical University, Zunyi 563003, Guizhou, China. ${ }^{3}$ The Engineering Research Center of Zunyi Precision Medical Detection and Birth Defects Prevention and Control, Affiliated Hospital of Zunyi Medical University, Zunyi 563003, Guizhou, China.

Published online: 06 August 2021

\section{Reference}

1. Wan X, Li L, Liu Z, Fan Z, Yu L. Recurrent spontaneous abortion related to balanced translocation of chromosomes: two case reports. J Med Case Rep. 2021;15:270. https://doi.org/10.1186/s13256-021-02848-9.

\section{Publisher's Note}

Springer Nature remains neutral with regard to jurisdictional claims in published maps and institutional affiliations. permits use, sharing, adaptation, distribution and reproduction in any medium or format, as long as you give appropriate credit to the original author(s) and the source, provide a link to the Creative Commons licence, and indicate if changes were made. The images or other third party material in this article are included in the article's Creative Commons licence, unless indicated otherwise in a credit line to the material. If material is not included in the article's Creative Commons licence and your intended use is not permitted by statutory regulation or exceeds the permitted use, you will need to obtain permission directly from the copyright holder. To view a copy of this licence, visit http://creativecommons.org/licenses/by/4.0/. The Creative Commons Public Domain Dedication waiver (http://creativecommons.org/publicdomain/zero/1.0/) applies to the data made available in this article, unless otherwise stated in a credit line to the data. 